\title{
Shaping Unconventional Gas Regulation: Industry Influence and Risks of Agency Capture in Texas, Colorado and Queensland
}

\author{
Cameron Holley, Tariro Mutongwizo, Clifford Shearing and Amanda \\ Kennedy*
}

\begin{abstract}
Unconventional gas has quickly become a significant energy resource and a site of contestation over the nature and outcome its regulatory processes. Central to this contest are issues of power and capture and the implications for achieving sustainable energy regulation. The influence of dominant industry players can be a serious obstacle for transitions beyond established energy regimes, and can negatively affect the sustainability of energy policy and implementation. Drawing on interviews across three case studies in Texas, Colorado and Queensland, this article examines perceptions of unconventional gas regulators and regulations. It finds a general view from interviewees that economic interests within the unconventional gas industry have influenced regulation, and that this influence is a significant explanation for the failures of regulation and policy to address a number of environmental and societal concerns. Variations are identified between the cases in terms of the extent of possible industry influence, but all three cases reveal common points of vulnerability, including economic arrangements, suboptimal organisational structures, expertise imbalances, limited agency funding and "revolving doors" of staff. The findings suggest that fully addressing these challenges through law alone will be difficult, and instead highlights three governance pathways that could be pursued beyond state law to achieve more effective and sustainable unconventional gas governance.
\end{abstract}

\section{INTRODUCTION}

Unconventional gas has been a context where a key source of engagement, between interests that favor and those who question the value of the use of hydrocarbons, has been the regulatory environment. ${ }^{1}$ These regulations have emerged with the intention of managing the mining and distribution of hydrocarbons in ways that will limit the harms that can and have emerged from the many multifaceted risks associated with unconventional gas as an energy source. ${ }^{2}$

\footnotetext{
* Cameron Holley is Professor, UNSW Law, UNSW Sydney, member of the Connected Waters Initiative Research Centre and the UNSW Global Water Institute; Dr Tariro Mutongwizo is Postdoctoral Fellow, UNSW Law, UNSW Sydney; Clifford Shearing is Professor, Griffith Criminology Institute, and School of Criminology and Criminal Justice, Griffith University, Faculty of Law, University of Cape Town and School of Criminology, University of Montreal. Amanda Kennedy is Professor, Queensland University of Technology, Brisbane. This article draws on work presented at a PLuS Alliance workshop, and was funded by an Australian Research Council Discovery Grant (DP170100281). Part of this Article draws on work previously published in Cameron Holley \& Amanda Kennedy, "Governing the Energy-Water-Food Nexus: Regulating Unconventional Gas Development in Queensland, Australia" (2019) 59(2) Jurimetrics 233 and Tariro Mutongwizo \& Cameron Holley, Hydraulic Fracturing in the Karoo: Critical Legal and Environmental.

${ }^{1}$ Anita George, "Are We on the Edge of a Global Energy Transformation?" (World Economic Forum, 2015) <https://www.weforum. org/agenda/2015/04/are-we-on-the-edge-of-a-global-energy-transformation/>; Cihan Sultanoglu, "Towards Low-Emission and Climate Resilient Economic Growth" (Keynote Speech, UNDP, 19 June 2015) <http://www.eurasia.undp.org/content/rbec/en/ home/presscenter/speeches/2015/6/29/cihan-sultanoglu-s-keynote-speech--towards-low-emission-and-clim.html>.

${ }^{2}$ For a summary and discussion on gas and energy, see E Moniz et al, The Future of Natural Gas: An Interdisciplinary MIT Study (MIT, 2011); V Smil, Natural Gas: Fuel for the 21st Century (Wiley, 2015) Ch 8. For a general discussion on pathways to cleaner
} 
Unconventional gases, such as shale gas and coal bed methane/coal seam gas (CSG), are now considered a "global phenomenon". ${ }^{3}$ Their promotion and commodification rests on a claim that slowing the emissions lock-in of coal in today's energy markets requires a mix of primary energy sources that include hydrocarbons. ${ }^{4}$ Given this, unconventional gas is said to provide a less carbon-intensive fuel source (relative to other fossil fuels), while still being abundant and feasible to access. ${ }^{5}$ Yet, the transition to unconventional gas has been met with a variety of environmental and social concerns, including risks of air pollution, noise and amenity concerns, subsidence, changes in the use of food-producing land, water pollution, reduced water availability and high methane emissions. ${ }^{6}$ Mann and Wainwright go so far as to argue that the uptake of fracking by countries such as the United States and China "signals the end of any hope for meaningful carbon mitigation". ${ }^{7}$ National and global projections suggest unconventional gas will remain a major part of global energy mixes for some time. ${ }^{8}$

Given this context, it is of paramount importance that the regulation of unconventional gas manages the many multifaceted risks and delivers sustainable outcomes - that is, outcomes that effectively protect crucial planetary boundaries, as well as other social concerns. ${ }^{9}$ This article focuses on the regulation of unconventional gas in order to explore an increasingly important issue in energy transition research - namely, issues of power and capture - and the implications for achieving sustainable energy regulation. ${ }^{10}$ Various studies have speculated on, and to a lesser extent examined, the risks of industry influence and government vulnerability to capture by the unconventional gas sector. ${ }^{11}$ The influence of

energy, see, eg, Jacqueline Peel and Hari Osofsky, Climate Change Litigation: Regulatory Pathways to Cleaner Energy (CUP, 2015); Neil Gunningham, "Managing the Energy Trilemma: The Case of Indonesia" (2013) 54 Energy Policy 184; World Energy Council, "Assessment of Energy Policy and Practices" (2008) <https://www.worldenergy.org/publications/2008/assessmentof-energy-policy-and-practices>; Michael Bradshaw, Global Energy Dilemmas (Wiley, 2014); Cameron Holley and Emma Lecavalier, "Energy Governance, Energy Security and Environmental Sustainability: A Case Study from Hong Kong" (2017) 108 Energy Policy 379.

${ }^{3}$ World Energy Council (WEC), "World Energy Resources, Unconventional Gas: A Global Phenomenon" (2016); Standing Council on Energy and Resources (SCER), "The National Harmonised Regulatory Framework for Coal Seam Gas" (2013).

${ }^{4}$ Michael Lazarus et al, "Natural Gas: Guardrails for a Potential Climate Bridge" in The New Climate Economy (Stockholm Environment Institute, 2015) 1; IEA, "Energy Supply Security: Emergency Responses of IEA Countries" (2014) 13; Ben Wah Ang, W Choong and T Ng, "Energy Security: Definitions, Dimensions and Indexes" (2015) 42 Renewable and Sustainable Energy Review 1077 (2015); IEA, "Energy and Air Pollution" (2016) 2.

${ }^{5}$ Although note that demand for unconventional gas remains uncertain: WEC, n 3, 4; Lazarus et al, n 4, 1.

${ }^{6}$ See Bryce Kelly et al, "Fugitive Methane Emissions from Natural, Urban, Agricultural, and Energy-Production Landscapes of Eastern Australia" in Geophysical Research Abstracts (Vol 17, 2015); Amanda Kennedy, Environmental Justice and Land Use Conflict: The Governance of Mineral and Gas Resource Development (Routledge, 2017); Cameron Holley and Darren Sinclair, "Rethinking Australian Water Law and Governance: Successes, Challenges and Future Directions" (2016) 33 EPLJ 275, 277; IEA, n 4, 2; Maria Comino, Poh-Ling Tan and David George, "Between the Cracks: Water Governance in Queensland, Australia and Potential Cumulative Impacts from Mining Coal Seam Gas" (2014) 23(6) Journal of Water Law 219; Kathryn Owens, "Strategic Regional Land Use Plans: Presenting the Future for Coal Seam Gas Projects in New South Wales?" (2012) EPLJ 113; Hennie Coetzee and Louis J Kotzé, "Shale Gas Development and Water in South Africa: Regulatory Aspects" in E Hollo (ed), Water Resource Management and the Law (Edward Elgar, 2017).

${ }^{7}$ Geoff Mann and Joel Wainwright, Climate Leviathan: A Political Theory of Our Planetary Future (Verso, 2018) Ch 2.

8 WEC, n 3; IEA, "World Energy Outlook" (2018) <https://www.iea.org/weo2018/>; The Scientific Inquiry into Hydraulic Fracturing in the Northern Territory, "Final Report of the Scientific Inquiry into Hydraulic Fracturing in the Northern Territory" (Northern Territory Government, 2018) (NT Inquiry).

${ }^{9}$ Johan Rockström et al, "A Safe Operating Space for Humanity" (2009) 461 Nature 472; Louis Kotzé (ed), Environmental Law and Governance for the Anthropocene (Hart Publishing, 2017).

${ }^{10}$ For a recent discussion of how elites shape transition agendas, see A Giridharadas, Winners Take All: The Elite Charade of Changing the World (Penguin, 2018).

${ }^{11}$ Elanor Andrews and James McCarthy, "Scale, Shale, and the State: Political Ecologies and Legal Geographies of Shale Gas Development in Pennsylvania" (2014) 4(1) Journal of Environmental Studies and Sciences 7; N Richardson et al, "The State of State Shale Gas Regulation" (Resources for the Future, 2013); Kennedy, n 6; Arno Kourula et al, "Intermediary Roles in Regulatory Programs: Toward a Role-Based Framework" (2018) Regulation and Governance 1; Benjamin K Sovacool, "How Long Will It Take? Conceptualizing the Temporal Dynamics of Energy Transitions" (2016) 13 Energy Research and Social Science 205; NT Inquiry, n 8, 385; Emily Grubert, "The Eagle Ford and Bakken Shale Regions of the United States: A Comparative Case Study" (2018) 5(4) The Extractive Industries and Society 570. See also related issues such as dwindling regulatory trust, politics and path 
dominant industry players can be a serious obstacle for transitions beyond established energy regimes, a phenomenon that has been well documented with respect to other energy industries. ${ }^{12}$ For example, fossil fuel incumbents can slow or block changes in energy regimes, as well as negatively affect sustainability of energy policy and implementation. ${ }^{13}$ Mindful that energy resources, social systems and government arrangements manifest differently in different contexts, the risks of industry dominance and capture will be neither monolithic nor identical. ${ }^{14}$ Accordingly, this article draws on three different cases to critically examine and compare variations (and lack thereof) of unconventional gas industry influence in regulatory processes, and to offer insights into the risks, causes and possible solutions to regulatory capture. ${ }^{15}$

It examines these issues in the context of two leading global unconventional gas producers, the United States and Australia. In both nations, regulatory primacy sits with State governments, with minimal federal involvement and relatively limited steering by local governments (eg through development and planning controls, provided they do not contradict State rules). ${ }^{16}$ The article focuses on three large unconventional gas-producing States where regulatory interventions have been implemented to manage extractive activities - Texas and Colorado in the United States, and Queensland in Australia. ${ }^{17}$ Based on the results of 45 interviews with public, private and non-government stakeholders, the study found that respondents perceived the regulatory playing field to be tilted, to varying degrees, in favour of the gas industry in all three States. The nature and causes of this apparent industry dominance are subsequently explored. Some solutions are offered for addressing risks of both perceived and actual regulatory capture through State law and institutions, as well as governance pathways outside of State regulation that may provide opportunities for greater sustainability in unconventional gas production contexts.

The article commences in Part II by briefly outlining literature on unconventional gas and risks of regulatory capture. Part III then sets out the methodology that informed the present study, before Part IV examines the findings. It begins by outlining perceptions across the three cases that economic interests within the unconventional gas industry have influenced regulation, and that this influence is a significant explanation for the failures of regulation and policy to address a number of environmental and societal concerns. It finds variation between the States in terms of the extent of possible industry influence, but

dependency: Ross M Carter and Richard K Morgan, "Regulatory Trust and Failure - A Case Study of Coal Seam Gas in New South Wales, Australia" (2018) 61(10) Journal of Environmental Planning and Management 1789; Andy Stirling, "Transforming Power: Social Science and the Politics of Energy Choices" (2014) 1 Energy Research and Social Science 83, 88; Charles Davis, "The Politics of 'Fracking': Regulating Natural Gas Drilling Practices in Colorado and Texas" (2012) 29(2) Review of Policy Research 178; Andreas Goldthau, "Conceptualizing the Above Ground Factors in Shale Gas: Toward a Research Agenda on Regulatory Governance" (2016) 20 Energy Research and Social Science 73.

${ }^{12}$ FW Geels, "Regime Resistance Against Low-Carbon Transitions: Introducing Politics and Power into the Multi-level Perspective" (2014) 31(5) Theory, Culture and Society 21; Derk Loorbach, Niki Frantzeskaki and Flor Avelino, "Sustainability Transitions Research: Transforming Science and Practice for Societal Change" (2017) 42 Annual Review of Environment and Resources 599; Christopher Carrigan, "Captured by Disaster? Reinterpreting Regulatory Behavior in the Shadow of the Gulf Oil Spill" in Daniel Carpenter and David A Moss (eds), Preventing Regulatory Capture: Special Interest Influence and How to Limit It (CUP, 2014) 239; see also Adam Mayer and Stephanie Malin, "How Should Unconventional Oil and Gas Be Regulated? The Role of Natural Resource Dependence and Economic Insecurity" (2019) 65 Journal of Rural Studies 79, for a brief review of the literature on resource dependence and acquiescence to industry in other regulatory and policy regimes.

${ }^{13}$ Nicholas A Ashford and Ralph P Hall, "Achieving Global Climate and Environmental Goals by Governmental Regulatory Targeting" (2018) 152 Ecological Economics 246, 246-247; A Smith, "Transforming Technological Regimes for Sustainable Development: A Role for Alternative Technology Niches?" (2003) 30(2) Science and Public Policy 127.

${ }^{14}$ For a discussion of how a particular socio-economic-political context has shaped an energy regime, see J Froestad et al, "South Africa's Minerals - Energy - Complex: Flows, Regulation, Governance and Policing" in Y Omorogbe and A Order (eds), Ending Africa's Energy Deficit and the Law: Achieving Sustainable Energy for All in Africa (OUP, 2018). See generally Geels, n 12; Matthew Lockwood et al, "Historical Institutionalism and the Politics of Sustainable Energy Transitions: A Research Agenda" (2017) 35(2) Environment and Planning C: Politics and Space 312, 319; Holley and Lecavalier, n 2; Gunningham, n 2.

${ }^{15}$ Loorbach, Frantzeskaki and Avelino, n 12, 612; Sovacool, n 11, 205; Lockwood, n 14, 319.

${ }^{16}$ Adrianne C Kroepsch, "Horizontal Drilling, Changing Patterns of Extraction, and Piecemeal Participation: Urban Hydrocarbon Governance in Colorado" (2018) 120 Energy Policy 469, 470. Note the recent proposals in Colorado for the PROTECT Bill

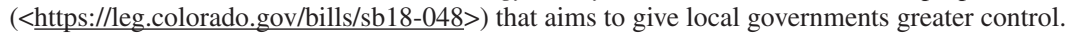

${ }^{17}$ IEA, "Unconventional Gas Production Database" <https://www.iea.org/ugforum/ugd/>. 
all three cases reveal common points of vulnerability, including economic arrangements, suboptimal organisational structures, an imbalance of expertise and information between industry and the regulator, poorly funded State agencies and "revolving doors" of staff between regulators and industry. The findings suggest that fully addressing these challenges through State law alone will be difficult, and highlights three governance pathways that could be pursued beyond the state to achieve more effective and sustainable unconventional gas governance. These pathways include influencing and utilising the social licence of leading industries (including leveraging public commitments by companies to act responsibly), the use of agreements and ordinances by local municipalities, and harnessing benchmarking bodies to ratchet up the regulatory performance of States.

\section{Unconventional Gas Regulation and Risks of Capture}

The speedy transition to unconventional gas in recent decades - "perhaps the most remarkable, and consequential, expansion of resource extraction in modern history"18 - has resulted in its increasingly vital role in meeting human energy requirements. As noted in our introduction to this Special Issue, there are many positive social and economic aspects to unconventional gas development. ${ }^{19}$ Yet, if the extraction of unconventional gas is inadequately governed, there is a risk of substantial, long-term adverse impacts on the environment and communities. ${ }^{20}$

At present, CSG is the most developed unconventional gas source in Australia, while shale reserves have been the primary source of unconventional gas in the United States. ${ }^{21}$ CSG is similar to its shale gas cousin (ie both being primarily comprised of methane); however, the location and process of extraction is often different. ${ }^{22} \mathrm{CSG}$ tends to be found in much shallower areas ( $<1$ kilometre/3,300 feet underground), whereas shale gas will often be at much greater depths (between 1.5 and 4 kilometres/4,900 and 13,000 feet underground) ${ }^{23}$ Both sources can require hydraulic fracturing (or "fracking"), which is the injection of high-pressure mixes of sand, water and chemicals to break the reservoir where the gas is trapped underground. ${ }^{24}$ However, fracking is required in less than half of CSG contexts, compared to almost always for shale gas extraction. This is because shale gas is found in less permeable rock formations, and fracking is typically required to break open these formations and release the gas. ${ }^{25}$ The result is that shale gas extraction uses more water to fracture rocks than water produced from underground. ${ }^{26}$ In

${ }^{18}$ Smil, n 2, 133. In Australia, for instance, coal seam gas accounted for one-third of Australian gas production and nearly twothirds of east coast gas production in 2016-2017: Department of the Environment and Energy, "Australian Energy Update 2018" (Australian Government, 2018).

${ }^{19}$ For a discussion of the advantages of methane $\left(\mathrm{CH}_{4}\right)$, particularly in combination with combustion turbines as an alternative to coal in the production of electricity, see Smil, n 2. Note that some economic changes, such as in rural communities, have also engendered increases in living costs and a fly-in-fly-out work force that can disrupt previously tight-knit agricultural communities: Jamie Pittock, Karen Hussey and Samuel McGlennon, "Australian Climate, Energy and Water Policies: Conflicts and Synergies" (2013) 44 Australian Geographer 1, 3.

${ }^{20}$ K Bowmer, "Water Resources in Australia: Deliberation on Options for Protection and Management" (2014) 21 Australian Journal of Emergency Management 228; John Williams, Tim Stubbs and Ann Milligan, "An Analysis of Coal Seam Gas Production and NRM in Australia" (The University of Queensland, 2012).

${ }^{21}$ For a summary of concerns related to hydraulic fracturing, see Smil, n 2, 138-139. In the Australian context, see PL Tan and J Robertson, "Compromising Confidence? Water, Coal Seam Gas and Mining Governance Reform in Queensland and Wyoming" in Cameron Holley and Darren Sinclair (eds), Reforming Water Law and Governance from Stagnation to Innovation In Australia (Springer, 2018).

${ }^{22}$ Smil, n 2; Tsuey Cham, "Shale Gas, Coal Seam Gas... What's the Difference?" (CSIROscope, 30 October 2014) <https://blog. csiro.au/shale-gas-coal-seam-gas-whats-the-difference/>.

${ }^{23}$ Cham, n 22.

${ }^{24}$ Denis Cooke, "Explainer: Coal Seam Gas, Shale Gas and Fracking in Australia", The Conversation, 16 August $2011<\underline{\text { https:// }}$ theconversation.com/explainer-coal-seam-gas-shale-gas-and-fracking-in-australia-2585>.

${ }^{25}$ Cooke, n 24.

${ }^{26}$ CSIRO, "What Is Unconventional Gas?" (2015) < https://www.csiro.au/en/Research/Energy/Hydraulic-fracturing/What-isunconventional-gas $>$. 
contrast, CSG is found in coal seams trapped underground by water pressure. ${ }^{27}$ The extraction process accordingly requires water to be pumped out to release the gas, leading to CSG often producing more water than it uses to "frack" the coal seams. ${ }^{28}$

Large volumes of water extracted during CSG development can dramatically increase pressure on already fully or over-allocated water systems. ${ }^{29}$ Depressurisation of the coal seam by multiple gas developments also risks major cumulative impacts that can severely reduce water availability, alter flows and damage water quality. ${ }^{30}$ While water consumption can also be a concern for shale gas, a more common concern is the migration of contaminated fluids or stray gases from the wellbore, induced seismicity from the injection of large volumes of water into formations, and spills of hydraulic fracturing fluids or wastewaters. ${ }^{31}$ Other negative externalities of unconventional gas extraction can include risks to human health, environmental and amenity impacts including noise and light pollution, and impacts to air quality (from the release of volatile organic compounds during the extraction process and also leaking from storage tanks, as well as dust from trucks and transport on site, usually during the initial drilling process). ${ }^{32}$

The above impacts and concerns have led to criticism of State law and policy regimes for their failure to attend to linkages and interdependences between unconventional gas and its environmental and social impacts. ${ }^{33}$ Such criticism has led some to claim that laws and policies are enabling the unconventional gas industry to override the public interest, thereby undermining sustainable outcomes. ${ }^{34}$ The emerging unconventional gas literature is replete with many possible explanations for such critiques (eg technocratic and scientific models that marginalise wider democratic engagement). ${ }^{35}$ Of interest to this article is the increasingly prominent line of argument that focuses on power asymmetries. ${ }^{36} \mathrm{~A}$ critical issue here has been industry influence and risks of regulatory capture. ${ }^{37}$

A multidimensional concept with a long history, ${ }^{38}$ capture is broadly concerned with the domination of the regulatory process by narrow, special interests for their own benefit and at the expense of the general public interests. ${ }^{39}$ Although risks of capture can arguably arise from any special interest, including

${ }^{27}$ Cooke, n 24; Cooke, n 26

${ }^{28}$ Cooke, n 24; Cooke, n 26.

${ }^{29}$ National Water Commission (NWC), "Coal Seam Gas and Water Position Statement" (2012); Pittock, Hussey and McGlennon, n 19.

${ }^{30}$ NWC, n 29.

${ }^{31}$ Tanya Gallegos, "Hydraulic Fracturing (Fracking)" (AccessScience, 2018).

${ }^{32}$ Cameron Thomas Whitley, "Engines, Sentinels, and Objects: Assessing the Impacts of Unconventional Energy Developments on Animals in the Marcellus Shale Region" in Anthony Ladd (ed), Fractured Communities: Risk, Impacts, and Protest Against Hydraulic Fracking in US Shale Regions (Rutgers University Press, 2018) 132; Theo Colborn et al, "An Exploratory Study of Air Quality Near Natural Gas Operations" (2014) 20(1) Human and Ecological Risk Assessment: An International Journal 86; Erik Kiviat, "Risks to Biodiversity from Hydraulic Fracturing for Natural Gas in the Marcellus and Utica Shales (2013) 1286(1) Annals of the New York Academy of Sciences 1.

${ }^{33}$ Karen Hussey, Jamie Pittock and Stephen Dovers, “Justifying, Extending and Applying 'Nexus' Thinking in the Quest for Sustainable Development” in J Pittock, K Hussey and S Dovers (eds), Climate, Energy \& Water (CUP, 2015).

${ }^{34}$ Comino, Tan and George, n 6; Kennedy, n 6; Hannah Wiseman, "The Capacity of States to Govern Shale Gas Development Risks" (2014) 48 Environmental Science and Technology 8376.

${ }^{35}$ Stirling, n 11, 88; Kennedy, n 6, 174-176.

${ }^{36}$ Loorbach, Frantzeskaki and Avelino, n 12, 614; Kennedy, n 6.

${ }^{37}$ Richardson et al, n 11; NT Inquiry, n 11, 385; JR Lozano-Maya and Juan Roberto, "Looking Through the Prism of Shale Gas Development: Towards a Holistic Framework for Analysis" (2016) 20 Energy Research and Social Science 63; Andrews and McCarthy, n 11; Kennedy, n 6; Ceit E Wilson et al, "Capture and Crush: Gas Companies in the Fracking Dispute and Deliberative Depoliticization" (2018) 92 Geoforum 106; Ceit Wilson et al, "Steering Social Outcomes in America's Energy Heartland: State and Private Meta-Governance in the Marcellus Shale, Pennsylvania" (2017) 47(8) The American Review of Public Administration 929; Mayer and Malin, n 12.

${ }^{38}$ G Stigler, “The Theory of Economic Regulation” (1971) 2(1) Bell Journal of Economics 3.

${ }^{39}$ Sidney A Shapiro, "The Complexity of Regulatory Capture: Diagnosis, Causality and Remediation” (2012) 102(1) Roger Williams University Law Review 101. 
environmental interests ${ }^{40}$ it is the dominance of economic interests that has been a primary explanation for failed environmental regulation, policy-making and enforcement. Indeed, regulators are more likely to face focused pressure from concentrated economic interests (eg regulated industries) than the general public or other interests, who lack the incentives and means to mobilise to protect broadly dispersed public goods, like environmental quality. ${ }^{41}$

There are few agreed metrics or measures of regulatory capture itself. Just because a policy or regulatory program is informed or supported by an industry group does not constitute capture or some wrongdoing per se - indeed, the existence of special interest lobby groups is an established feature of contemporary democracies. ${ }^{42}$ This makes measuring regulatory capture quite difficult, and requires the arguably complex consideration of when regulation is intentionally moved away from the service of one goal (a broadly conceived public interest) towards another (a narrowly defined industry interest) ${ }^{43}$ This further demands an understanding of public interest and intent - both tricky to define ${ }^{44}$ For instance, identifying or measuring the public interest has long been a thorny problem, and there are many ways it could be defined, including expressed statutory intent, issues of welfare, the views of democratic majorities, legislation supported by legitimate parliamentary majorities, and so on. Similarly, identifying intent by industry to actively and knowingly push regulation away from the public interest is challenging. ${ }^{45}$ Industry may benefit from regulation because their actions are producing "shared value", or because of a range of unintentional factors, including bureaucratic drift, coincidence, mistakes or due to a by-product of public-serving regulation. ${ }^{46}$

Capture is, by definition, complex. ${ }^{47}$ Carpenter and Moss distinguish between strong capture (eg where the public would be better served by complete replacement of policy or an agency) and weak capture (eg where industry influence compromises the capacity of regulation to enhance the public interest, but the public is still being served by regulation, relative to the baseline of no regulation).$^{48}$ According to Carpenter and Moss, "some amount of weak capture may well be fairly ubiquitous". ${ }^{49}$ Indeed, as regulatory thinking and practice has matured (and mentalities such as neoliberalism have spread), the perceived line between public and private interests have become increasingly blurred. ${ }^{50}$ New models of regulation invoke industry and non-government actors in partnerships, flexible rule-making, marketbased instruments, voluntarism and self-regulation, partly in an effort to be effective while being less burdensome on regulated entities. ${ }^{51}$ Certainly this can lead to improvements in regulatory practice;

\footnotetext{
${ }^{40}$ W Tucker, "Environmentalism: The Newest Toryism" (1980) 14 Policy Review 141.

${ }^{41}$ A Downs, An Economic Theory of Democracy (Harper \& Row, 1957); M Olson, The Logic of Collective Action: Public Goods and the Theory of Groups (Harvard University Press, 1965); DA Farber, "Politics and Procedure in Environmental Law" (1992) 8 Journal of Law, Economics and Organization 59, 60.

${ }^{42}$ Carter and Morgan, n 11, 1790. See Kennedy, n 6, 61-71 for an example of this from the State of New South Wales, where policy changes relevant to the assessment of extractive development "prioritised" the economic benefit of extracting mineral and petroleum resources over and above other factors. Industry lobbying for the development of this policy and the fact that the change came in the wake of a Land and Environment Court decision to overturn approval of a coalmine, were widely criticised.

${ }^{43}$ Daniel Carpenter and David A Moss, "Introduction" in Daniel Carpenter and David A Moss (eds), Preventing Regulatory Capture: Special Interest Influence and How to Limit it (CUP, 2014) 12.

${ }^{44}$ Carpenter and Moss, $\mathrm{n}$ 43, 12.

${ }^{45}$ Carpenter and Moss, $\mathrm{n} 43,13-14$.

${ }^{46}$ Carpenter and Moss, n 43, 13-14; M Porter and M Kramer, "Shared Value: How to Reinvent Capitalism - and Unleash a Wave of Innovation and Growth" (2011) Jan/Feb Harvard Business Review 1.

${ }^{47}$ Carpenter and Moss, n 43, 12; M Levine and J Florrence, "Regulatory Capture, Public Interest, and the Public Agenda: Toward a Synthesis" (1990) 6 Journal of Law, Economics, and Organization 167, 178; T Makkai and J Braithwaite, "In and Out of the Revolving Door: Making Sense of Regulatory Capture" (1992) 12(1) Journal of Public Policy 61.

${ }^{48}$ Carpenter and Moss, $\mathrm{n}$ 43, 12.

${ }^{49}$ Carpenter and Moss, n 43, 12.

${ }^{50}$ Carpenter and Moss, $\mathrm{n} 43,9$.

${ }^{51}$ See generally P Drahos (ed), Regulatory Theory Foundations and Applications (ANU Press, 2017); Carter and Morgan, n 11, 1790-1791; Brock Facione, "Regulatory Capture of Mineral Management Agencies and the Diminishing Regulation of US Oil and Gas Industries" (Southern University Law Center, 2017).
} 
however, these alternative approaches to governance are also not immune to risks of rent-seeking and capture. ${ }^{52}$ Further, industry influence can be difficult to track - it may not necessarily be overt, and may be shaped by framing tactics deeply embedded in political and industry narratives. ${ }^{53}$ For these reasons, others have identified the need to unveil and decipher the "power geometries" within governance frameworks, particularly where collective decision-making is involved.$^{54}$ Power can be structural (based upon economic and political frameworks), material (based upon objects) or even discursive (based upon language), ${ }^{55}$ where it can be used to constrain policy development by prioritising certain scales of assessment (eg regional economic interests over local environmental concerns), promote particular ideologies (including historical perspectives) or exclude interests that do not fit within the dominant paradigm. ${ }^{56}$ Accordingly, the "constellation of laws, actors, institutions and dynamics" 57 should be scrutinised to determine how - and to what extent - power is mobilised in the service of particular interests. $^{58}$

While definitive answers on the nature and extent of regulatory capture within unconventional gas regulation are virtually impossible, by drawing on the views of the interviewees, the findings below unpack perceived risks and potential forms of influence within unconventional gas regulation, and the impact this has on regulatory legitimacy and trust. The findings echo growing attention in the energy arena to issues of power and risks of regulatory capture..$^{59}$ On one level, this is perhaps not surprising. As Lozano-Maya puts it, the governance of unconventional gas regulation is "at heart ... a political undertaking [that] creates asymmetrical benefits and risks in different spatial and temporal scales, leading to disputes among stakeholders" ${ }^{60}$ Energy and unconventional gas regulation has traditionally fallen within the domain of States, including subnational States, which have long been recognised as vulnerable to (and/or evidencing) capture by industry. ${ }^{61}$ Even so, debates continue in the literature as to whether and to what extent - industries, including those in the extractive sector, capture regulators. Some have suggested in the United States that those with mineral rights and landowners "call the shots", rather than industry; ${ }^{62}$ indeed, in some cases, States and subnational States have imposed strict regulation or outright bans on unconventional gas extraction in response to public concerns. ${ }^{63}$ However, a number of analysts have identified greater risks of industry dominance in unconventional gas regulation - for

${ }^{52}$ Carter and Morgan, n 11, 1790-1791; Makkai and Braithwaite, n 47; Facione, n 51; Wilson et al (2018), n 37.

${ }^{53}$ Kennedy, n 6, 175; Kroepsch, n 16; Mayer and Malin, n 12; Wilson et al (2018), n 37; Elen Stokes, "Regulatory Domain and Regulatory Dexterity: Critiquing the UK Governance of 'Fracking'" (2016) 79(6) The Modern Law Review 961; Christopher E Clarke et al, "Public Opinion on Energy Development: The Interplay of Issue Framing, Top-of-Mind Associations, and Political Ideology" (2015) 81 Energy Policy 131.

${ }^{54}$ NC Heynen, M Kaika and E Swyngedouw, In the Nature of Cities: Urban Political Ecology and the Politics of Urban Metabolism (Taylor \& Francis, 2006); Tiffany H Morrison et al, "Mitigation and Adaptation in Polycentric Systems: Sources of Power in the Pursuit of Collective Goals" (2017) 8 Wiley Interdisciplinary Reviews: Climate Change 5.

${ }^{55}$ Gordon Walker, Environmental Justice: Concepts, Evidence and Politics (Routledge, 2012).

${ }^{56}$ Kennedy, n 6.

${ }^{57}$ Benjamin E Apple, "Mapping Fracking: An Analysis of Law, Power, and Regional Distribution in the US" (2014) 38 Harvard Environmental Law Review 217, 243.

${ }^{58}$ Morrison et al, n 54.

${ }^{59}$ Barbara Warner and Jennifer Shapiro, "Fractured, Fragmented Federalism: A Study in Fracking Regulatory Policy" (2013) 43 The Journal of Federalism 474; Richardson et al, n 11; Facione, n 51; Kennedy, n 6.

${ }^{60}$ Lozano-Maya and Roberto, n 37, 67; For more on uncertainty, risk and regulation, see generally F Haines, "Regulation and Risk" in P Drahos (ed), Regulatory Theory Foundations and Applications (ANU Press, 2017).

${ }^{61}$ Warner and Shapiro, $\mathrm{n} 59$; although note there is ongoing debate about benefits of decentralisation relative to centralisation and critiques that States risk a race to the bottom; see, eg, Jacqueline Peel and Lee Godden, "Australia Environmental Management: A 'Dams' Story" (2005) 28(3) UNSW Law Journal 668; Robert Baldwin and Martin Cave, Understanding Regulation: Theory, Strategy and Practice (OUP, 1999) 36.

${ }^{62}$ Thomas W Merrill and David M Schizer, "The Shale Oil and Gas Revolution, Hydraulic Fracturing, and Water Contamination: A Regulatory Strategy” (2013) 98 Minnesota Law Review 145, 253.

${ }^{63}$ See, eg, Minister of Resources, "Fracking Banned in Victoria, Giving Certainty to Farmers" (Victorian Premier's Department, 7 March 2017) <https://www.premier.vic.gov.au/fracking-banned-in-victoria-giving-certainty-to-farmers/>. 
example, because State agencies remain underfunded or because of the broader economic benefits to be gained from gas extraction. ${ }^{64}$ In the United States, for instance, Warner and Shapiro suggest there is a higher risk of capture of State government unconventional gas regulations, given the absence of specific federal regulation to act as a backstop. ${ }^{65}$ A similar claim may be levelled at Australia, notwithstanding recent attempts to provide some national leadership through federal environmental assessment on water impacts, independent expert advisory committees, bioregional assessments and proposals for national harmony in regulation (though many of these processes are reliant on State assessment and information). ${ }^{66}$ What remains unclear is when and how the unconventional gas industry may dominate or capture State regulatory programs, particularly beyond obvious and overt forms of corruption. The broader literature on environmental regulation identifies a range of reasons for industry dominance, ${ }^{67}$ including a lack of political independence (particularly where lobbying from industry is high), an imbalance of expertise and information between industry and the regulator, suboptimal legal and organisational arrangements (eg a regulator is situated within an agency that is also responsible for promoting resource development), poorly funded organisations and the "revolving doors" of staff between regulators and industry. ${ }^{68}$ The following part draws on these categorisations to explore perceptions and risks of capture in the case studies.

In the face of such risks, analysts have identified various means of resisting or reducing such capture, not least being representation by and actions of NGOs in regulatory processes. ${ }^{69}$ Concepts such as tripartism in business regulation ${ }^{70}$ and countervailing powers have been used to describe the actions of NGOs, which use their knowledge, skills and position in regulatory decision-making, forums and the public sphere to reduce, and perhaps even neutralise, the power-advantages of ordinarily powerful actors. ${ }^{71}$ Although dependent on capricious factors (eg factors that give rise to social movements as well as lower barriers to collective action generally), success has occurred via NGOs exploiting broad-based social pressures and demands that arise in the wake of salient, high-profile issues. ${ }^{72}$

Ultimately, there is a need for further empirical study to identify the risks, causes and solutions to power asymmetries and regulatory capture in the distinctive structure and politics of unconventional gas extraction. This study aims to advance understanding of these issues.

\section{MethodS}

The project compares unconventional gas regulation in two of the globe's leading unconventional gas nations, namely the United States and Australia. The United States is the largest producer of shale and CSG production; between 2000 and 2015 the proportion of United States (US) natural-gas production

\footnotetext{
${ }^{64}$ Merrill and Schizer, n 62, 243; Nikolaos Zirogiannis et al, "State Regulation of Unconventional Gas Development in the US: An Empirical Evaluation" (2016) 11 Energy Research and Social Science 142, 147.

${ }^{65}$ Warner and Shapiro, n 59; Zirogiannis et al, n 64, 147. Note former President Obama's attempts, since overturned by the Trump administration, to regulate methane emissions.

${ }^{66}$ Environment Protection and Biodiversity Conservation Act 1999 (Cth) s 24D; SCER, n 3.

${ }^{67}$ M Bernstein, Regulating Business by Independent Commission (Princeton University Press, 1955); W Gormley, "A Test of the Revolving Door Hypothesis at the FCC" (1979) 23(4) American Journal of Political Science 665.

${ }^{68}$ Carter and Morgan, n 11, 1790; N Gunningham, "Negotiated Non-Compliance: A Case Study of Regulatory Failure" (1987) 9 Law and Policy 69; JQ Wilson (ed), The Politics of Regulation (Basic Books, 1980); Makkai and Braithwaite, n 47.

${ }^{69}$ Wilson, n 68; Gormley, n 67; D Thornton, RA Kagan and N Gunningham, "Compliance Costs, Regulation, and Environmental Performance: Controlling Truck Emissions in the US" (2008) 2 Regulation and Governance 275, 275-276.

${ }^{70}$ I Ayres and J Braithwaite, "Tripartism: Regulatory Capture and Empowerment" (1991) 16 Law and Social Inquiry 435; Braithwaite J, "Accountability and Governance under the New Regulatory State" (1999) 58(1) Australian Journal of Public Administration 90.

${ }^{71}$ A Fung and E Wright, "Countervailing Power in Empowered Participatory Governance" in A Fung and E Wright (eds), Deepening Democracy: Institutional Innovations in Empowered Participatory Governance (Verso, 2003) 273-275.

${ }^{72}$ Fung and Wright, n 71, 283-284; Thornton, Kagan and Gunningham, n 69, 276; Farber, n 41. See also Carter and Morgan, n 11, 1790.
} 
from hydraulically fractured wells increased from $7 \%$ to $67 \% .{ }^{73}$ Australia is home to significant unconventional gas resources, including approximately $10 \%$ of the world's CSG reserves. Australia is also set to surpass US production of CSG by $2020,{ }^{74}$ and presently $97 \%$ of Australia's CSG production is occurring in the State of Queensland (with shale gas extraction prominent on the horizon). ${ }^{75}$ Although shale and CSG extraction remain different processes, comparing across State regulatory regimes is arguably appropriate because both give rise to somewhat similar environmental impacts. Further, despite some differences, the two nations share broadly similar democratic and federal structures. Recognising that the large majority of unconventional gas regulation occurs at a State level in both nations, the study zeros in on some of the highest producing States in the United States and Australia - namely Texas, Colorado and Queensland. All three of these case studies have relatively mature systems of gas regulation (see Table 1 for a brief overview), and were selected given their efforts to implement various instrumental and institutional interventions relevant to unconventional gas. Utilising semi-structured interviews to elicit opinions and experiences of the respective State regulatory systems in practice ${ }^{76}$ the study selected approximately 15 experts per case study (45 in total) across State, federal and municipal governments, industry, non-government interests, academic experts and lawyers who have acted for gas companies, environmental NGOs and community groups. The interviews were conducted in 2017-2018 to capture recent trends and changes over time in regulatory policy and implementation. The interview data was analysed using Adaptive Theory and coding to identify common themes. ${ }^{77}$

TABLE 1. Overview of State Regulation in Texas, Colorado and Queensland

\begin{tabular}{|c|c|c|c|c|}
\hline & Main State Agencies & Main Regulations & $\begin{array}{l}\text { Assessment and } \\
\text { Approval Process }\end{array}$ & Compliance \\
\hline Texas & $\begin{array}{l}\text { - Primary regulator: } \\
\text { Railroad Commission } \\
\text { of Texas (RRC). } \\
\text { - Air impacts: Texas } \\
\text { Commission on } \\
\text { Environmental Quality } \\
\text { (TCEQ). }\end{array}$ & $\begin{array}{l}\text { - Natural Resources Code } \\
\text { - State-wide rules (eg } \\
\text { Rule } 32 \text { on flaring; } \\
\text { Rule } 29 \text { on Hydraulic } \\
\text { Fracturing Disclosure). }\end{array}$ & $\begin{array}{l}\text { - No or minimal } \\
\text { environmental } \\
\text { assessment. } \\
\text { - Permits (drilling; } \\
\text { air). } \\
\text { - Disclosure through } \\
\text { FracFocus. }\end{array}$ & $\begin{array}{l}\text { - } \mathrm{RRC} \text { and } \\
\text { TCEQ. }\end{array}$ \\
\hline Colorado & $\begin{array}{l}\text { - Primary regulator: } \\
\text { Colorado Oil and } \\
\text { Gas Conservation } \\
\text { Commission (COGCC). } \\
\text { - Air impacts: } \\
\text { Department of } \\
\text { Public Health and } \\
\text { Environmental } \\
\text { Quality. }\end{array}$ & $\begin{array}{l}\text { - Colorado Oil and Gas } \\
\text { Conservation Act. } \\
\text { - Colorado Habitat } \\
\text { Stewardship Act. } \\
\text { - COGCC policies and } \\
\text { rules. }\end{array}$ & $\begin{array}{l}\text { - Permits, including } \\
\text { environmental } \\
\text { review, location } \\
\text { assessments, } \\
\text { water and soil } \\
\text { assessments. } \\
\text { - Disclosure through } \\
\text { FracFocus. }\end{array}$ & $\begin{array}{l}\text { - COGCC and } \\
\text { Department } \\
\text { of Public } \\
\text { Health and } \\
\text { Environmental } \\
\text { Quality. }\end{array}$ \\
\hline
\end{tabular}

\footnotetext{
${ }^{73}$ US Energy Information Administration, "Hydraulically Fractured Wells Provide Two-thirds of U.S. Natural Gas Production" (5 May 2016).

${ }^{74}$ Andrea Walton et al, "Resilience in a Changing Community Landscape of Coal Seam Gas: Chinchilla in Southern Queensland" (2013) 15 Journal of Economic and Social Policy 3.

75 Queensland Government, "Petroleum and Gas Resources" < https://www.business.qld.gov.au/industries/invest/mining/ resources-potential/petroleum-gas $>$.

${ }^{76}$ Note that the study does not focus on unconventional gas extraction on federal land.

${ }^{77}$ D Layder, Sociological Practice Linking Theory and Social Research (Sage Publishing, 1998) 19.
} 
Table 1. continued

\begin{tabular}{|c|c|c|c|c|}
\hline Queensland & $\begin{array}{l}\text { - Primary regulators: } \\
\text { Department of Natural } \\
\text { Resources, Mines and } \\
\text { Energy; Department } \\
\text { of Environment and } \\
\text { Science. } \\
\text { - Groundwater impacts: } \\
\text { Office of Groundwater } \\
\text { Impact Assessment. }\end{array}$ & $\begin{array}{l}\text { - Petroleum and Gas } \\
\text { (Production and Safety) } \\
\text { Act } 2004 \text { (Qld). } \\
\text { - Environmental } \\
\text { Protection Act } 1994 \\
\text { (Qld). } \\
\text { - State Development } \\
\text { and Public Works } \\
\text { Organisation Act } 1972 \\
\text { (Qld). } \\
\text { - Water Act } 2000 \text { (Qld). } \\
\text { - Codes for land access } \\
\text { and make good } \\
\text { agreements. }\end{array}$ & $\begin{array}{l}\text { - Environmental } \\
\text { Impact Statement } \\
\text { and Environmental } \\
\text { Authority (EA). } \\
\text { - Surat Cumulative } \\
\text { Management Area. }\end{array}$ & $\begin{array}{l}- \text { CSG } \\
\text { Compliance } \\
\text { Unit (multi- } \\
\text { disciplinary } \\
\text { industry and } \\
\text { environmental } \\
\text { staff from } \\
\text { across } \\
\text { government) }\end{array}$ \\
\hline
\end{tabular}

\section{FINDINGS}

\section{Perceptions on Industry Dominance and Potential for Regulatory Capture}

Across Texas, Colorado and Queensland, regulation has long been applied to unconventional gas production. Although each State has a slightly different regulatory approach and organisational structure (see Table 1), regulations variously prescribe disclosure rules, ${ }^{78}$ well construction requirements, permitting requirements, monitoring requirements, offences and, in the case of Queensland and Colorado, forms of environmental assessment. All have been subject to periodic reforms to improve regulation (eg Colorado's Oil and Gas Commission Reform Act 2007 changed the composition of the COGCC and environmental requirements, Queensland introduced codes for negotiated agreements between landholders, and Texas introduced rules on disclosure of chemicals).

Respondents across the cases reported many strengths in their respective State's regulations. Broadly speaking, interviewees saw States, rather than federal governments, as better suited to regulate the gas industry, because it is complex, involves rapid technology developments and has largely localised impacts. ${ }^{79}$ As one national NGO respondent put it: "I still think that States are able to respond to change more quickly than the Federal government ... it's better than a one-size-fits-all top-down regulatory structure." ${ }^{80}$ In relation to the State case studies specifically, Colorado was often praised as having some of the earliest and most comprehensive methane regulations, and its baseline water monitoring was lauded for its forward-looking approach. ${ }^{81}$ In Queensland, improved cumulative modelling of groundwater impacts over time and ongoing enforcement and compliance programs were also considered to have increased regulatory effectiveness ${ }^{82}$ Finally, some respondents in Texas noted its regulation was "about as mature as any state in the nation ... and it's a pretty tight ship". ${ }^{83}$ In particular, the disclosure rules in Texas were considered to have improved the ability for monitoring fracking activity, particularly among the bigger gas companies.

\footnotetext{
${ }^{78}$ However, some concerns are evident in the literature regarding disclosure of chemicals on websites such as FracFocus. Although there have been improvements to the website overtime, it has been argued that it makes important data available but does so in a manner that limits accessibility and reduces the comprehensibility of environmental assessment. See Kourula et al, n 11, 11. This was also noted by one of the interviewees: Interview Lawyer2T.

${ }^{79}$ For further discussion on the nature of different levels of government in regulating unconventional gas, see generally David B Spence, "Federalism, Regulatory Lags, and the Political Economy of Energy Production" (2012) 161 University of Pennsylvania Law Review 431.

${ }^{80}$ Interview NGO1N.

${ }^{81}$ Interview Community Representative2C.

${ }^{82}$ Interview Agriculture Association1Q.

${ }^{83}$ Interview Science1T.
} 
Many of the interviewees also noted the importance of gas production to the States' economies (discussed further below) and its significance in providing orderly energy transitions. As one industry respondent put it: "In the medium-term gas is a fundamental enabler of wind and solar - because without base wind and solar can't cope with demands." ${ }^{84}$ These types of benefits led some respondents to reflect on the need for a regulatory environment that facilitated, rather than hindered, unconventional gas production. Notwithstanding such views, there were widely held opinions that each State regulatory regime confronted a number of weaknesses. It is not possible within the scope of such a short article to fully detail all of the criticisms of these regimes; however, for the purposes of illustration, a few examples are noted below.

\section{Example 1: Queensland - Environmental Assessment and Adaptive Management Challenges}

Various weaknesses were identified in Queensland's framework, particularly regarding water management. ${ }^{85}$ One of the primary means for assessing CSG developments is environmental assessment processes on water and other environmental resources under both Queensland and federal law (eg the Environment Protection and Biodiversity Conservation Act 1999 (Cth)). These and related requirements have gone some way to managing CSG's nexus with water, and to a lesser extent food-producing land, including the introduction of Cumulative Management Area assessments. Even so, respondents noted there were major shortcomings regarding the environmental approval and assessment process. Indeed, the majority of respondents were of the opinion that most of the assessment processes had failed to fully account for the cumulative impacts of CSG development on water, land and environmental issues.

As one natural resource non-government respondent bluntly explained: "[C]umulative impacts like surface water quality or biodiversity, increased fragmentation for example, were effectively not being assessed." Further hampering consideration of cumulative impacts was the lack of a strong information base about regional water and land conditions. As another environmental NGO interest put it: "[T]here's so much uncertainty in groundwater impacts that it doesn't seem to be working ... we need better expertise in the Department." Further, what information CSG companies did have was rarely shared with the public or potential competitors (ie other CSG companies), which hampered the ability to fully assess the impacts of multiple CSG developments. As one government respondent noted, this led to an adaptive conditioning process that arguably "caused a lot of harm along the way":

This is what happens in Queensland. They're given the tenure and the adaptive management thing says,

'We'll deal with the risks as they arise'. So, the environmental considerations become a secondary thing...[it was] the opposite to the precautionary principle, the way it was used.

\section{Example 2: Texas - Siting Issues, Rules on Spill Reporting and Orphan Wells}

One of the significant challenges in Texas, as one government respondent put it, is "dealing with development in urban areas and development that was a different intensity than we had seen". ${ }^{86}$ As extraction moved closer to urban areas, municipalities such as Denton in Texas began implementing bans against fracking due to the proximity of wells to schools and neighbourhoods. Less than a year later the State government introduced the HB40 Bill, which overrode outright bans in Denton and other local areas (but noted that municipalities could adopt commercially reasonable regulations for surface activities). As one environmental NGO described their battle against HB40:

[T] he industry is very powerful, they employ I think something like a million people in the state, and revenue from oil and gas funds the legislature, all of state government, and our schools - in general I think politicians are deferential to them. Then you also have that they spend a lot of money in campaign contributions and lobbying efforts to further seal the deal, such that we don't have a whole lot of support, so even among Democrats on the HB 40 vote, I think we ended up getting something like 18 or 20 votes out of 150 against that bill. So we're just vastly out-gunned in support of that.

Respondents also pointed to a range of shortfalls in rules, including a failure to consistently require State-wide spill reporting of produced water, and addressing orphaned wells (notwithstanding the fact that Texas has periodically reviewed regulations and well inventories). As one legal expert put it: "Orphan wells and capping and closing. Enormous issue here in Texas. There's no budget for it. There's not good teeth in the regulations to force those operators who are going bankrupt or otherwise to close those. It presents threats to groundwater and all these other issues."

\footnotetext{
${ }^{84}$ Interview Industry1Q.

${ }^{85}$ Interview NGO NRM1Q; Interview NGO Environment1Q; Interview Government2Q; Interview LawyerT1; Comino, Tan and George, n 6.

${ }^{86}$ Interview Government1T; Interview NGO Environment1T; Interview NGO Environment3T.
} 


\section{Example 3: Colorado - Bans, Setbacks and Balancing Interests}

Colorado's regulations have been ranked by Zirogiannis et al's study as one of the more robust in terms of stringency and protection. ${ }^{87}$ However, this ranking was based on the law on the books, rather than in its implementation, and it is here where challenges are now emerging. As Colorado's population continues to grow, there are significant conflicts developing between industry developments and urban populations, who fear health impacts, air pollution, as well as safety issues. Indeed, safety became particularly prominent in 2017 following an uncapped flowline that contributed to a house explosion, which killed two people and injured two people. Akin to the State of Texas (eg Denton), these concerns saw attempts by local municipalities, such as Fort Collins and Longmont, to pursue outright bans. However, these bans were ultimately overturned by the Colorado Supreme Court for impeding State interests. As one academic interviewee characterised this growing conflict in urban areas:

[O]il and gas production 30 years ago would have still been out in the prairie land in Colorado, without anyone in sight. And communities, as they grew 30 years ago, they wouldn't dream of building out in these vast prairies. But what we've seen over time is that these two are running into each other and that's where a lot of the strain is within the state.

On many accounts, current regulation is considered insufficient for addressing urban citizens' concerns. As one legal representative explained:

Colorado, you know never turns down any oil and gas development in any location regardless of what the impacts are, or how close it is to nearing communities. It's led to a lot of big conflicts, so particular there's one case where the state has approved a large, I think it's twenty-four well pad right behind a middle school. The state had no problem and their position is that they're supposed to be encouraging oil and gas development and, as long as they can check the boxes of complying with the minimum requirements of their rules, they approve any oil and gas site and this had led to a lot of backlash.

This backlash has included a recent 2018 battle over setback distances from production sites (Proposition 112) moving the distance from 1,500 to 2,500 feet. This was subsequently countered by industry with a proposed amendment of the State Constitution to give property owners the right to seek compensation for any reduction in property value caused by State laws and regulations (Proposition 74). With neither provision ultimately winning the necessary support, the challenge of addressing these concerns remains live. Most recently, the Supreme Court found in favour of the State in the case of Martinez $v$ COGCC, where arguments that human health should be prioritised over resource development were rejected on the basis that the development of oil and gas resources could be balanced against the need "to prevent and mitigate significant environmental impacts to the extent necessary ... only after taking into consideration cost-effectiveness and technical feasibility".

As can be seen from the examples above, there were mixed views on the effectiveness of each regulatory regime. For many of the non-industry interviewees, the regulatory deficiencies identified were perceived as directly attributable to the dominance of industry, and their power of influence ${ }^{88}$ over governments to set the scale and pace of regulatory responses. This was put most strongly in the case of Texas:

I would say that a lot of it has to do with agency capture by the industry, particularly in states like Texas where the industry has gotten what it wanted for years and years, very difficult to change that culture. ... Once you open the door to allowing industry to basically get what it wants, they're just going to take it, and they're going to take it at every step. ${ }^{89}$

Other respondents, including legal and academic experts, noted how Texas' primary regulatory body, the Railroad Commission, was "being controlled by a government institution so heavily tilted towards the industry". ${ }^{90}$ As another respondent from an environmental group described it: "[E]ven though we know

\footnotetext{
${ }^{87}$ Zirogiannis et al, n 64; Sam Lounsberry, "Anadarko Reaches Settlement with Families of Victims, Survivors of Firestone House Explosion", The Denver Post, 23 May 2018_<https://www.denverpost.com/2018/05/23/anadarko-firestone-explosion-lawsuitsettlement/>; Interview Academic1C; Interview Lawyer1C; City of Fort Collins v Colo Oil and Gas Ass'n 369 P.3d 586 (2016 CO 28, No 15SC668); City of Longmont v Colo Oil and Gas Ass'n 369 P.3d 573 (2016 CO 29, No 15SC667); Colorado Oil and Gas Conservation Commission v Martinez 2019 CO 3 (No 17SC297); see also Jacy Marmaduke, "Colorado Supreme Court: No Health, Safety Mandates for Oil, Gas Regulators in Latest Ruling", Coloradoan, 14 January $2019<$ https://www.coloradoan.com/ story/news/2019/01/14/cogcc-v-martinez-colorado-supreme-court-rules-favor-oil-and-gas-group/2570771002/>.

${ }^{88}$ Maartje Van Lieshout et al, "The Power to Frame the Scale? Analysing Scalar Politics Over, In and Of a Deliberative Governance Process" (2017) 19(5) Journal of Environmental Policy and Planning 550.

${ }^{89}$ Interview Academic2C.

${ }^{90}$ Interview Lawyer2T.
} 
there are regular routines and sometimes flagrant violations of the law, they [the Commission] bend over backwards to try and suggest there are no environmental problems with fracking, the industry's doing just fine." 91

As recognised in the literature, Colorado and Texas have chosen very different regulatory paths for fracking - Colorado has emphasised greater environmental protection, whereas Texas has focused on more resource extraction and development. ${ }^{92}$ It is not surprising then that refrains of outright capture were less common in Colorado, tending instead to coalesce around industry dominance and recent siting decisions. Certainly, historical concerns of capture were noted, including major industry "clout" and decision-makers previously suffering from "a fully captured board" (prior to the 2008 amendments). ${ }^{93}$ However, even in recent times, as one legal expert pointed out:

$[\mathrm{T}]$ he state and the industry at every turn have fought off regulation. ... Now the state does have authority to go beyond their minimum requirements, they just almost never do or they do like very little.... And that has really led us to the point where now communities are just fed up, I mean the government is not protecting their interest, industry is fighting against regulation at every turn. ${ }^{94}$

In Queensland, respondents held a spectrum of views, including one NGO representative who claimed that "the regulation is rubbish. It's self-regulation". ${ }^{95}$ Other NGO representatives were less critical, but noted regulatory deficiencies arose because of the gas industry's privileged position as the primary information holder on the effects of extraction:

Government is entirely dependent on companies for a lot of information. The companies are the ones best positioned to do baseline studies. It is tricky for government to afford to do the research to get the information - they need industry, but once industry does it and gives the government the raw data, the company has already invested heaps of money, and so of course it tells the government that everything will be okay. ${ }^{96}$

Perceptions of capture and industry dominance varied between individual interviewees. For those who raised capture or industry influence, it was clear there was significant respect for the individuals employed at agencies. The integrity or willingness of the staff was never questioned. However, in each State it was recognised that the actions of these staff and the agencies themselves were significantly constrained by various barriers, discussed further below. Whether this could be defined as outright capture remains debatable; it is certainly difficult to irrefutably demonstrate clear industry intent or achievement of "strong" regulatory capture (as defined above). It should also be noted that successful countervailing lobbying from environmental groups has also reportedly influenced regulations. For example, conservation groups in Colorado succeeded in achieving changes in a 2008 rewriting of regulations to protect wildlife. As one community group representative put it, "the conservation community was very well organised and they made sure that wildlife was part of the conversation the whole way through. So much so that they changed the mission to make sure that it included wildlife in there". ${ }^{97}$ Similarly, in Queensland, Statebased NGOs were reported as doing "some pretty pointed advocacy with government and got some rules changed" 98 around evaporation ponds and the need for cumulative management assessments for groundwater (the latter coming after many projects had been approved). In Texas, environmental groups were also reported as engaging the legislature "to help pass a law requiring disclosure of chemicals ... [and] fought HB 40". ${ }^{99}$

\footnotetext{
${ }^{91}$ Interview NGO Environment1T.

${ }^{92}$ Jonah J Ralston and Jason A Kalmbach, "Regulating Under Conditions of Uncertainty and Risk: Lessons Learned from State Regulation of Hydraulic Fracturing" (2018) 20(2-3) Environmental Practice 68.

${ }^{93}$ Interview NGO EnvironmentN2.

${ }^{94}$ Interview Lawyer1C.

${ }^{95}$ Interview NGO NRM4Q.

${ }^{96}$ Interview NGO NRM3Q.

${ }^{97}$ Interview Community Representative2C.

${ }^{98}$ Interview NGO Environment2Q.

${ }^{99}$ Interview NGO Environment1T.
} 
Nonetheless, it was striking that many interviewees considered industry dominance and, in some cases, regulatory capture as a palpable and identifiable cause of governance weakness (and in some cases, failure) in each State. What was evident from many of the interviewees was a perception that the regulatory system favoured industry over a number of environmental and community concerns, which served to explain the reactive regulation of the industry, where problems were slow to be fixed and regulation and policy were perceived as responding inadequately to environmental and societal risks. The following section fleshes out some of the identified causes of these perceptions of industry influence, and the vulnerabilities this poses for the legitimacy of regulatory regimes. ${ }^{100}$

\section{The Causes of Perceived Industry Influence and Risks of Regulatory Capture}

Although explanations for perceived industry influence varied, including political lobbying at the very top of the law-making system, the majority of respondents suggested the vulnerability of State regulation to accusations of industry influence arose from a combination of economic arrangements, suboptimal organisational arrangements, an imbalance of expertise and information between industry and the regulator, poorly funded State agencies, and "revolving doors" of staff between regulators and industry. Each of these is contemplated in turn below to further explore how perceptions of industry influence and risks of regulatory capture arise, and how they can erode trust and confidence in governance systems.

\section{Economic Arrangements}

Respondents across all three cases raised concerns about unconventional gas and its role in broader economic arrangements within their States. In particular, they pointed to the historical legacy and structural features that favoured industry interests over environmental ones. In both Texas and Colorado, respondents pointed to a history of laws being drafted in favour of industry. As one community representative observed, there was "a long term legacy, since however many decades, of just the way the laws have been written, they were written by industry. ... So there is a bit of a capture that's probably historical in nature". ${ }^{101}$ Indeed, as Davis has argued in Colorado, there are various historic laws and policies that provide substantial tax deductions and subsidies, and enable increased density of wells. ${ }^{102}$

Unsurprisingly, one of the major reasons why industry was perceived to have had influence over regulations was the significant economic returns (also a notable factor in public interest) they provided. In Colorado, for instance, depending on the year and the prices, energy, oil and gas make up about 3-6\% of the economy. Such economic returns were considered to be a factor in the State's successful court challenge noted above against some local municipality bans. As one academic expert explained:

This isn't rocket science - if you curtail the industry or constrain the industry it will have a negative economic impact. So you would forego billions of dollars in oil and gas production and you would forego those jobs. You would forego the taxes. The way we tax the industry in Colorado it ends up summing depending on the prices - ends up summing to between $\$ 500$ million and $\$ 1$ billion every year in taxes at the local level. So you're putting a lot of that value at risk. ${ }^{103}$

A similar set of circumstances pervaded Texas, where some of the earlier bans in municipalities such as Denton were ultimately overruled. As one respondent explained:

One third of the economy of Texas is still oil and gas and that's worrisome. They have potential for renewables, solar and wind should work well and if you go to the Panhandle, there are a gazillion wind farms, but I - think it will take a political decision to really reduce the reliance of the state on oil and gas and that will not happen because ... we don't pay state taxes, mostly because the state gets a lot of money from oil and gas, so we are too reliant on that to assume that fracking will go down. The Texas Legislature

\footnotetext{
${ }^{100}$ Julia Black, "Constructing and Contesting Legitimacy and Accountability in Polycentric Regulatory Regimes" (2008) 2(2) Regulation and Governance 137.

${ }^{101}$ Interview Community Representative2C.

${ }^{102}$ Davis, $\mathrm{n} 11,185$.

${ }^{103}$ Interview Academic1C.
} 
has been very good at preventing local regulation from differentiating themselves if they think that they are not business friendly. ${ }^{104}$

As a result, respondents believed it was unlikely that anyone was able to put too much pressure on the gas industry. As one academic expert noted: "[T]hey pretty much can do whatever they want to do."105

In Queensland, despite a comparatively younger history in unconventional gas extraction, respondents pointed to a similar tendency of laws to be industry-leaning, in part because of the royalties the government receives from its development, the boost to the State economy and very good industry lobbying on both counts. The CSG industry boomed in Queensland at an economically vulnerable time for the State, coinciding with the commencement of the Global Financial Crisis in 2009/2010. During this period, the Queensland government saw potential for royalties from CSG development, and despite the absence of significant policy or legislation for CSG per se, they arguably rushed to pursue and promote the industry. As one government respondent went on to note:

One of the things that happened, APIA and the Resources Council were very good lobbies. The global financial crisis had hit. Government was struggling to balance budgets. The lobbies rolled in and said this will solve your problems. 170 million was the projection, but actual royalties were 34 million. Industry oversold royalty benefits and government swallowed it, hook, line and sinker. ${ }^{106}$

The reported result was a significant political desire to push projects through assessment and approval processes under rushed timeframes. As one environmental NGO representative explained: "This is seen as once in a generation opportunity to turn rates and dollars for the state. So there was immense pressure on the bureaucrats that were processing those applications ... those approvals were pushed through on really flimsy evidence basically." 107

\section{Organisational Arrangements}

The independence of a regulator is seen as a badge of honour, shielding operations from interference and influence by politics and industry power that can produce capture. Each of the three cases evidenced concerns over regulator independence, albeit to varying degrees. On the one end of the spectrum was Colorado, where reforms to the COGCC had shifted opinions of its operations from being "fully captured" 108 to one that represented a more balanced mix of interests. Even so, the under-resourced nature of the COGCC led one NGO representative to claim its operations were ineffectual, and thus served broader industry interests:

The Colorado Oil and Gas Commission. ... I think we have found it to be incredibly problematic in terms of oversight of the oil and gas industry, very similar to our politicians it feels very much like it's just another paid for branch by the oil and gas industry ... this regulatory arm, is not doing its due diligence when we have something like 28 regulators for the entire state for 55,000 active wells. I mean, it is absolutely absurd. ${ }^{109}$

In the middle of the spectrum, Queensland's agencies were seen as lacking an "independent regulator", with departments responsible for environmental protection and mines accountable to the same minister. ${ }^{110}$ Similar risks have been raised in other States and Territories. ${ }^{111}$ Attempts in Queensland to create an independent dispute resolution body, known as the Queensland GasFields Commission, were (prior to legislative and organisation reforms in 2017) ${ }^{112}$ also criticised as having been subject to regulatory capture

\footnotetext{
${ }^{104}$ Interview Academic4T.

${ }^{105}$ Interview Academic4C.

${ }^{106}$ Interview Government1Q.

${ }^{107}$ Interview NGO Environment2Q.

${ }^{108}$ Interview NGO EnvironmentN2.

${ }^{109}$ Interview NGO Environment4N.

${ }^{110}$ Interview Government2Q.

${ }^{111}$ NT Inquiry, n 8, 385.

${ }_{112}$ As with the 2008 reforms in Colorado, subsequent changes to the GasFields Commission in Queensland occurred in 2017, including changes in composition and board membership.
} 
by the unconventional gas industry, and failing to adequately protect the interests of landholders. ${ }^{113}$ As one government respondent claimed: "[T]he GasFields commission - I call them WOFTMs - "waste of flaming time and money'. They went out and insulted landholders front and centre. Credibility was zero." 114

Finally, at the more extreme end, the primary regulator in Texas - the Railroad Commission - was widely seen as lacking independence, with the oil and gas industry being one of the only industries that was effectively carved out of Texas' Commission on Environmental Quality (aside from TCEQ regulating air emissions from gas extraction sites). As one academic expert characterised this: "There is the rest of the universe, and there is Texas oil and gas." ${ }^{115}$ Moreover, the Railroad Commission's organisational structure was controlled by elected commissioners, who were allowed to raise money from a variety of sources, including "a lot of finance for campaigns from industry" ${ }^{116}$ Even though respondents noted that "staff tend to be very good. Very talented. Very objective. Want to do the right thing", they noted the Railroad Commission was "widely criticised - a classic captive-type regulatory entity". ${ }^{117}$

\section{The Problem of Revolving Doors}

The term "revolving doors" was used by several respondents to describe the movement of personnel between regulators and industry, and the perceived subsequent conflicts of interest and influence that resulted from such movement. ${ }^{18}$ This was noted as a common phenomenon in Colorado and Queensland, although not expressly raised in Texas. ${ }^{119}$ For example, Colorado interviewees pointed to regulators "often" leaving government to work for the industry or to be lawyers for the industry. One example was explained as follows:

[T] he previous director [of a regulatory commission] ... before he had publicly announced his resignation, his new lobbing firm was listing him on their website while he was still a government employee... So they don't even bother to wait until after he's no long a public employee to be touting his government ties and being able to help and advise clients. Another former director, is now kind of a prominent oil and gas lawyer.... So it's kind of the path as you go and you work for the regulator for a few years and then you go cash up by making a lot of money on the other side. ${ }^{120}$

Similar stories were detailed in Queensland, with one farmer questioning the monitoring and management of the industry because of "the revolving door ... whichever day it is they'll be one or the other". ${ }^{121}$ The perceived consequence, as one NGO respondent explained, was that:

[T]here's this cross-fertilisation that goes on. ... The industry plays both sides of politics. So, it doesn't matter who is in power; there is always someone on the inside track in government or close to government with really strong networks back into industry and they can get what they want. They've got a lot of money. ${ }^{122}$

As discussed below, however, this exchange of expertise may almost have been a necessary condition, given the rapid pace of fracking technology and the reported lack of expertise and capacity on the part of government regulators.

\footnotetext{
${ }^{113}$ NT Inquiry, n 8, 348.

${ }^{114}$ Interview Government1Q.

115 Interview Academic2T.

${ }^{116}$ Interview Enironment1T; Interview Environment2T.

${ }^{117}$ Interview Lawyer1T.

${ }^{118}$ See generally Gormley, n 67; Makkai and Braithwaite, n 47, for more on the concept of "revolving doors" and the potential for regulatory capture.

${ }^{119}$ The reasons for this are unclear, but could include the fact that the Commission is controlled by elected officials, as well as the longer history of oil and gas regulation in Texas, giving them closer expertise and understanding of industry.

${ }^{120}$ Interview Lawyer1C.

${ }^{121}$ Interview Farmer1Q.

${ }^{122}$ Interview NGO NRM4Q.
} 


\section{Imbalance of Information, Expertise and Resources}

The fracking process and its rapid expansion through technology development (eg horizontal drilling) involves complexity and uncertainty for any regulator. ${ }^{123}$ Combined with commercial-in-confidence information (eg chemicals, technology), regulators across all three States reportedly faced a major challenge gaining information about the industry to enable a proactive regulatory approach. One lawyer from Colorado characterised the general situation as follows: "I think there are clearly agencies or components of agencies that suffer from capture more when they are dealing with things that no one understands except for the few highly regulated industrial actors." ${ }^{124}$ Respondents in Texas made a similar point, with one academic expert noting: "[T]he regulator is captured by the industry. And part of that is by virtue of the regulators needing to understand what the industry regulations should be." 125

Respondents from Queensland, where regulation is more recent, noted even less experience and information among government agencies - notwithstanding opportunities to learn from places in the United States, like Colorado. The result, according to one government respondent, was that the regulators:

didn't know what they were doing. They were doing catch-up all the time. It was a reactive policy, flexible, as things unfolded we said, "oh shit we better do that". The bureaucracy wasn't ready to deal with it. We didn't learn from the US experiences ... we learned from first principles ourselves. ${ }^{126}$

While learning from first principles allowed contextual refinements, one farming interest group respondent strongly believed "the industry is in charge, they have all of the power. The government ... just does as they're told and is led by the nose and does exactly what's requested of them with no thought to the implications even for their own survival". ${ }^{127}$ Compounding this challenge of information deficits was a general view that the agencies lack sufficient funding for their work. As one Texas government and US NGO respondent put it, "[f]unding for regulatory programs is a perennial challenge" 128 and "the regulators are doing the best they can with the resources they have. ... I would say they are all underresourced relative to the enormous work that they have to do. From the industry perspective, you know, they never really move fast enough". ${ }^{129}$

\section{Addressing Vulnerabilities and Pathways Forward}

Although Texas, Queensland and Colorado have taken different regulatory approaches to unconventional gas, their regulatory systems have all courted controversy. On the one hand, State-based regulation has variously facilitated environmental assessments, chemical disclosures, limited methane emissions, established setbacks and land access requirements. These rules have arguably managed and/or limited a number of potential harms to the environment and communities, while producing economic benefits for companies, employees, the State government and the public that benefit from their services. Periodic legal and institutional reforms have also been undertaken to address weaknesses and complaints of bias, and some of these changes have been spurred by environmental and community lobbying.

Despite these developments, it was clear from the interviews that unconventional gas regulation continues to confront criticisms of regulatory shortfalls. These included concerns over air and health impacts arising from the proximity of developments to urban populations and public places, and a failure to adequately account for cumulative impacts on the environment. These shortfalls were repeatedly attributed to

\footnotetext{
${ }^{123}$ Cooke, n 24.

${ }^{124}$ Interview Lawyer5C.

${ }^{125}$ Interview Academic2T.

${ }^{126}$ Interview Government1Q.

${ }^{127}$ Interview Farmer1Q.

${ }^{128}$ Interview Government1T.

${ }^{129}$ Interview NGO1N; Interview Govenrment1T. "We have the Railroad Commission. Even if they wanted to do a good job regulating, and some of the people at the lower levels do. But even if they wanted to, they don't have enough of them. This development is everywhere. It's everywhere. There is no way that they can possibly inspect all these wells every year. So some of them - we did a report several years ago and found that some of the wells hadn't been inspected for five years": Interview Environment NGO2T.
} 
perceived industry influence over governments and regulatory processes. While the nature of this study makes it difficult to confirm to what extent (if at all) the regimes themselves may be considered as "captured", it was clear that many interviewees viewed aspects of industry involvement as problematic. Such findings echo a number of concerns raised in the literature, and in the findings of some recent inquiries, about the regulation of unconventional gas (and similar large energy developments). ${ }^{130}$

The findings identified a range of vulnerabilities in regulatory and institutional structures that have created (and in many cases have continued to create) opportunities for industry to influence State regulatory systems. These included economic arrangements, suboptimal organisational arrangements, an imbalance of expertise and information between industry and the regulator, limitations in resourcing for regulators and revolving doors of staff between regulators and industry. Irrespective of whether these opportunities were actually realised, the legitimacy of regulatory regimes has been questioned, and the reputation of both regulators and industry has also suffered.

Taking these vulnerabilities and concerns on face value, it needs to be asked: what can concerned stakeholders do to reduce such vulnerabilities and level out the playing field to provide additional protections for the environment and communities? At least two overlapping pathways appear available across the case studies - namely, reforming State regulatory systems and/or pursuing alternative governance pathways outside of regulation. The first pathway, State regulatory reform, could involve numerous intervention points. One extreme and likely long-term reform would be to encourage direct federal regulation (or at minimum greater federal intervention) in unconventional gas regulation, particularly at a "constitutive regulation" level. ${ }^{131}$ Such changes would likely involve major political and policy hurdles. A medium-term option may be to build further support and traction for existing countervailing powers, such as environmental and conservation interests, which have evidently enjoyed some success in reforming State laws. It has been suggested that the power and capacity of industry to fund wide-reaching public relations campaigns, positioning unconventional gas as a "clean" alternative to other fossil fuels that provides financial salvation to struggling communities, has had a pervasive influence on regulatory and policy design, corralling public support while also crowding out alternative perspectives. ${ }^{132}$ While strengthening alternative perspectives that do not have the benefit of a broad platform holds some promise, there was a general view from respondents that unconventional gas regulation was often outside the purview of many large environmental groups (who tended to focus on big-ticket campaign issues such as the Great Barrier Reef in Queensland or wildlife conservation in Colorado), which could weaken their impact. Even so, it is possible that new coalitions could be built (eg as with Lock the Gate in Australia) ${ }^{133}$ to counter the perceived dominance of the gas industry. Environmental interests may also find alignment with renewable energy interests, which has already acquired a significant economic stake in some States (eg wind in Texas and Colorado, and solar in Queensland). However, this was seen to be a distant achievement, and in all States it was acknowledged that the renewable industry, as yet, holds far less sway than the more well-resourced oil and gas industry.

A more pragmatic set of options may be to encourage, and build support for, addressing specific weaknesses (see eg the recent propositions on setbacks in Colorado) and reforms designed to reduce some or all of the vulnerabilities raised above. Indeed, there are numerous steps that State governments could take to address most of these perceived vulnerabilities, including introducing new transparency laws, ${ }^{134}$ restructuring departments to foster greater independence, introducing more stringent laws

\footnotetext{
${ }^{130}$ Kennedy, n 6; NT Inquiry, n 8.

${ }^{131}$ C Shearing, "A Constitutive Conception of Regulation" in J Braithwaite and P Grabosky (eds), Business Regulation and Australia's Future (Australian Institute of Criminology, 1993) 67-79.

${ }^{132}$ Kennedy, n 6; Ann M Eisenberg, "Beyond Science and Hysteria: Reality and Perceptions of Environmental Justice Concerns Surrounding Marcellus and Utica Shale Gas Development" (2015) 77 University of Pittsburgh Law Review 183; Carlo Sica, "Stacked Scale Frames: Building Hegemony for Fracking Across Scales" (2015) 47(4) Area 443.

${ }^{133}$ Drew Hutton, "Lessons from the Lock the Gate Movement" (2012) 31(1) Social Alternatives 15.

${ }^{134}$ Greater transparency was raised by a number of respondents. "The industry have learned a lot of lessons from some of the bad old days from some of the things that were done wrong early in the process. Implementing appropriate regulation and again, transparency which I think is the most important as far as I'm concerned, in this industry anyway, is the most important thing": Interview Science2C.
} 
on movement of staff between government and regulated industries, and increasing funding for administrative agencies. ${ }^{135}$ However, it is important not to throw the baby out with the bathwater, so to speak. In the case of implementing tougher restrictions on staff movement between government and industry, for example, it is worth bearing in mind that the "revolving door" can be a positive phenomenon, broadening the capacity of staff and strengthening the knowledge and experience of industry and government. ${ }^{136}$ Zaring argues that the revolving door "has become an overused shorthand for - at its worst - a toxic cynicism about government", noting that the passage of staff between industry and government may not necessarily be motivated by capture, with human capital and market expansion incentives potentially also at play. ${ }^{137}$ The critical question, therefore, is whether such movements impair regulatory performance, and the challenge for both industry and regulators is to manage perceptions of vulnerability accordingly.

Of course, one may also be sceptical about how readily such changes would be delivered. Indeed, the extent of industry influence could act as a barrier that dampens the pace of meaningful change. This has been a wider challenge in energy transitions, where incumbents have worked within existing regimes to slow down change and efforts to achieve greater sustainability. ${ }^{138}$ In such contexts, it has been argued that adapting, changing and transforming existing dominant cultures, structures and practices require new "niches", governance experimentation and new relations that will ultimately destabilise existing regimes. ${ }^{139}$

What, then, might be some of these experiments outside of existing State systems that may help to shine a light on a more balanced and sustainable regulatory approach? At least three promising developments emerged from the findings, and all point to ways in which relationships between industry, government and society might be reconfigured to pursue more sustainable solutions and minimise accusations of "capture".

First, there has been growing interest in the unconventional gas space (including from respondents) in targeting the industry's social licence. ${ }^{140}$ As shown in other contexts, many companies are increasingly confronted by the fact that a legal licence to cause harm may not prevent concern over their impacts on society. Pressure from NGOs, community groups and others can encourage companies to lift their standards beyond legal minimums, often because of bad press, shareholders' concerns or the (economic) benefits of being seen to be a "good" neighbour and corporate citizen. ${ }^{141}$

Respondents reported mixed views on the effectiveness of pressuring gas companies and their social license. As some saw it, industry culture and environmental management approaches varied greatly, and not all would be prone to caring about their social impacts. ${ }^{142}$ Instead, there was a view that attention

\footnotetext{
${ }^{135}$ See generally Carpenter and Moss, $\mathrm{n} 43$.

${ }^{136}$ Wentong Zheng, “The Revolving Door” (2014) 90 Notre Dame Law Review 1265.

${ }^{137}$ David T Zaring, "Against Being against the Revolving Door" (2013) 2 University of Illinois Law Review 507, 507. Zaring cautions against altogether eliminating the revolving door at risk of developing a "caste-like professional and permanent bureaucracy": 546. See also Marc T Law and Cheryl X Long, "Revolving Door Laws and State Public Utility Commissioners" (2011) 5(4) Regulation and Governance 405, who found that revolving door laws can sometimes have unintended consequences, including reducing the expertise and employment prospects of government officers in particular, suggesting that there is a delicate trade-off between reducing the likelihood of capture, and regulator quality.

${ }^{138}$ Loorbach, Frantzeskaki and Avelino, n 12, 614.

${ }^{139}$ Loorbach, Frantzeskaki and Avelino, n 12, 614-616; Lozano-Maya and Roberto, n 37; Goldthau, n 11.

${ }_{140}$ Nina Hall et al, "Social Licence to Operate: Understanding How a Concept Has Been Translated into Practice in Energy Industries" (2015) 86 Journal of Cleaner Production 301; John Whitton et al (eds), Governing Shale Gas: Development, Citizen Participation and Decision Making in the US, Canada, Australia and Europe (Routledge 2018); Lozano-Maya and Roberto, $\mathrm{n} 37$.

${ }^{141}$ Hall et al, n 140; N Gunningham, RA Kagan and D Thornton, Shades of Green (Stanford University Press, 2003).

${ }^{142}$ As one environmental respondent put it: "[T]here is a wide disparity in personalities in energy companies. Some very good. Some not good at all... there's a spectrum as always I think. And it tends - the ones who both talk about social licence and will at times negotiate on a middle ground regulation tend to be the larger - either super major or majors. And then there are increasingly a number of I would say mid to small but not tiny independents that are reformed by investors not by experienced industry operators. That is their financial - people drawn in by finances, not by wanting to produce a product. They tend to cut corners and be very you know, frankly - bad neighbours. They don't care. And we're seeing an increase of that with the shale because they're often
} 
should focus on larger, reputation-sensitive and leading companies. ${ }^{143}$ Such companies were reportedly more open to community relations and environmental management, and had the economic means to lift their performance (eg pursuing deeper consultation processes with affected citizens, implementing innovative environmental management processes, or limiting their emissions) and in doing so, lever change across the industry.

Obviously, bringing social pressures to bear on companies risks "greenwashing" and tokenistic responses. Even so, respondents suggested it offered a strategic way of achieving shorter-term gains, while engaging in longer-term battles to improve State regulatory systems. This two-track approach was presented as follows: a wider campaign would be pursued to rebalance and improve the overall regulatory regime; industry, seeing the spectre of regulatory change on the horizon, would seek to fend off such regulatory change; in doing so, leaders would remain live to limiting bad news stories and be more prone to responding to social pressure for actions beyond the mere regulatory bottom line. As one respondent put it: "[T]he big companies realise they don't want to go there (overregulation). They have enough money and foresight to think ahead on some of those things, from a social acceptance point of view." 144 On a more optimistic reading, the subsequent improvements in the leaders' practices would in-turn show how regulations could be improved and applied across the wider industry, providing a positive feedback loop to the campaign for broad regulatory system reform.

A second, and related, option for new governance solutions was the use of agreements between operators and affected local communities (perhaps represented by regional and local governments/municipalities). Historically, negotiated agreements have been between a regulator and regulated industry; ${ }^{145}$ however, in the unconventional gas space, there are examples of these types of contractual arrangements between industry and affected landholders and communities. There was a general view that agreements held some promise for addressing the impacts of industry on communities and the local environment (eg impacts on water). In Colorado for instance, some companies and municipalities had entered into Memorandums of Understanding that were praised by one community representative as being " $[\mathrm{m}]$ uch more nimble than trying to get a law passed for sure. And I think that there's a lot of value that comes out of them because they can be tailored for what that community would like to see protected ... allow local governments to actually have a voice for constituents at the local government level to feel like that they're being heard". ${ }^{146}$ This flexibility was seen to be an important way to go beyond minimum requirements of State regulation that respondents saw as inadequate or preventing desired approaches (ie local bans).

Notably, across the States it was clear that success of such agreements depended on efforts to balance power between companies and affected landholders/communities, such as through independent negotiated information-sharing and resourcing. As one mediator described it: "[W]here there's a combination of real leverage, real negotiating power, and also some skilfulness around creative problem-solving, those are the most successful outcomes ... like setbacks or certain guarantees for things, whatever it is."147 While there are debates about how binding and enforceable such agreements may be, ${ }^{148}$ these approaches appeared to offer a more formalised and localised attempt at influencing social licenses, and leveraging change in the performance of the gas industry through tools outside of State regimes.

running on borrowed money. So it's been a - there was always a big operator/little operator split in the industry and the [crossstates]" (Interview NGO Environment2).

${ }^{143}$ See, eg, Gunningham, Kagan and Thornton, n 141; Christine Parker, The Open Corporation (CUP, 2002).

${ }^{144}$ Interview Science2C.

${ }^{145}$ See Adrienne Héritier, "New Modes of Governance in Europe: Policy Making Without Legislating?" (Working Paper No 81, Political Science Series, Institute for Advanced Studies, 2002); E Orts and K Deketelaere, Environmental Contracts: Comparative Approaches to Regulatory Innovation in the United States and Europe (Kluwer, 2001).

${ }^{146}$ Interview Community Representative2C

${ }^{147}$ Interview Mediator1C.

${ }^{148}$ See, eg, Skylar Zilliox and Jessica M Smith, "Supraregulatory Agreements and Unconventional Energy Development: Learning from Citizen Concerns, Enforceability and Participation in Colorado" (2017) 4 The Extractive Industries and Society 69. 
A third and final approach that emerged from the findings shares shades of democratic experimentalist scholarship. ${ }^{149}$ This places significant emphasis on monitoring and co-ordination of decentralised experiments in regulation, with a view to stronger accountability (through benchmarking), facilitating horizontal diffusion of best practice, and the lifting of regulatory bottom lines. The regulation of unconventional gas would seem ripe for such an approach, given the abundance of "State laboratories". While this vision is sometimes seen as idealistic, there is at least one example in the United States where a non-government body is beginning to implement this benchmarking approach. Known as STRONGER, this non-profit, multi-stakeholder, educational organisation comprises equal representation from the oil and gas industry, State oil and gas environmental regulatory agencies, and the environmental public advocacy community. Its primary role is developing guidelines for State oil and gas environmental regulatory programs (from cut and dry administrative matters to technical details for waste management and elements for hydraulic fracturing and air quality), and publishing State review reports against the criteria of those guidelines. ${ }^{150}$ In an effort to deliver continuous improvement of State oil and gas environmental regulatory programs, the organisation uses guidelines as a foundation for State reviews, bringing together different agencies to evaluate the overall program and identify things they are doing well and things that they could improve on against the criteria of the guidelines. Ultimately this alignment of different interests, information-sharing and some benchmarking against guidelines was claimed by one NGO representative to "help States in a lot of ways to tighten their regulations ... going through this evaluation process you're not real likely to kind of decide on a looser regulatory program or looser requirements". ${ }^{151}$ Approaches like this (perhaps backed by federal government or another organisation) could help spread learning, ratcheting up performance of State regimes and potentially lessen vulnerabilities to industry influence. Ultimately, such multi-level and polycentric governance is more likely to "significantly affect the incentives that bring about mutually beneficial outcomes for the stakeholders involved". ${ }^{152}$

\section{Conclusion}

As Goldthau notes, it is the "above ground factors ... [of] policies, regulation and institutional settings that determines the success or failure of a contested, risk bound technology". ${ }^{153}$ Through examining three leading global unconventional gas producers - Texas, Colorado and Queensland - this article has focused on one such "above ground factor" that can hamper the success of regulating unconventional gas transitions: the potential for industry influence and capture, and the implications for achieving sustainable energy regulation. The study found that respondents perceived the regulatory playing field to be tilted in favour of the gas industry in all three States, at the expense of more socially and environmentally optimal outcomes.

Perceptions of industry influence and risks of capture mainly resulted from under-regulation variously attributed to an imbalance of expertise and information between industry and regulators, suboptimal legal and organisational arrangements, poorly funded State agencies, economic returns and revolving doors of staff between regulators and industry. Evidently, addressing these challenges would be difficult, therefore, we propose governance pathways that include the use of agreements and ordinances by local municipalities, influencing the social licence of leading industries, and harnessing third parties to benchmark States and intensify regulatory performance. Future research on how transitions in other spheres have managed to avoid or reduce regulatory capture would be of benefit, as would research into how independent regulatory bodies can be established and relied on where transitions are taking place such as in the energy space.

\footnotetext{
${ }^{149}$ For a general discussion, see James Bohman, "Democratic Experimentalism" (2013) 29 Social Philosophy Today 7.

${ }^{150}$ STRONGER, "State Reviews" < https://www.strongerinc.org/state-reviews/>.

${ }^{151}$ Interview NGO1N.

${ }^{152}$ Lozano-Maya and Roberto, n 37, 70.

${ }^{153}$ Goldthau, n 11, 73.
} 